\title{
Additional Greenhouse Gas Emissions and Offset Potential from Sugarcane Straw Recovery for Bioenergy Production in Southern Brazil
}

Eduardo Barretto de Figueiredo ( $\nabla$ eduardobfigueiredo@hotmail.com )

Federal University of Sao Carlos: Universidade Federal de Sao Carlos https://orcid.org/0000-0003-32320933

\section{Susantha Jayasundara}

University of Guelph

Ricardo de Oliveira Bordonal

CTBE: Laboratorio Nacional de Ciencia e Tecnologia do Bioetanol

\section{Alan Rodrigo Panosso}

UNESP: Universidade Estadual Paulista Julio de Mesquita Filho

Newton La Scala Jr.

UNESP: Universidade Estadual Paulista Julio de Mesquita Filho

\section{Research Article}

Keywords: Renewable energy, Soil emissions, Harvest systems, Diesel consumption, Climate change

Posted Date: November 29th, 2021

DOI: https://doi.org/10.21203/rs.3.rs-1072167/v1

License: (a) (i) This work is licensed under a Creative Commons Attribution 4.0 International License. Read Full License

Version of Record: A version of this preprint was published at Carbon Footprints on February 22nd, 2023. See the published version at https://doi.org/10.20517/cf.2022.21. 


\section{Abstract}

This study was designed to assess the additional greenhouse (GHG) emissions including measurements of soil $\mathrm{CO} 2$-C emissions in sugarcane areas plus emissions associated with the recovery and transport operations of straw bales up to the factory gate for electricity production, contrasting with leaving all straw on the soil surface. The total additional GHG emissions considering the main sources evaluated (i.e ., soil $\mathrm{CO} 2$ - $\mathrm{C}$, diesel use and $\mathrm{N} 2 \mathrm{O}$ from straw), was estimated at $1,465 \mathrm{~kg}$ CO 2 eq ha -1 , resulting an emission factor of $212.6 \mathrm{~kg} \mathrm{CO} 2$ eq ton -1 of straw recovered. Applying the parameters cited in this study for electricity or $2 \mathrm{G}$ ethanol production (GHG balance of emission and offset potential), our results showed that straw-based for electricity production would result in additional GHG emissions of (+) $860 \mathrm{~kg} \mathrm{CO} 2 \mathrm{eq}$ ha -1 . In contrast, applying the same study parameters for $2 \mathrm{G}$ ethanol production replacing gasoline, an avoided GHG emission of (-) 2,316 kg CO 2 eq ha -1 could be achieved. The route of recovering around $27 \%$ of sugarcane straw through bale system for bioelectricity production using technical parameters and industrial efficiency rate of this study could not be a sustainable option because the additional emissions can be higher than its potential to offset generated emissions, based on the emission factor of Brazilian energy matrix. Applying the same experimental parameters, the option of producing ethanol $2 \mathrm{G}$ with around 6.89 ton DM ha -1 of sugarcane straw could offset gasoline GHG emissions, contributing with sustainable energy systems.

\section{Introduction}

Inventorying greenhouse gas (GHG) balance related to sugarcane (Saccharum officinarum) based byproducts is critical to assess the degree of carbon (C) neutrality of biofuels production [1] and, the advances to better support renewable energy source and the sustainability parameters, including GHG balance of these bioenergy sources should be better investigated to support public policies. The latest effort worldwide comes in the form of Law 13.576/2017 for the fostering of biofuels in Brazil, which creates the National Biofuel Policy, officially known as RenovaBio Program, which will create a controlled market of decarbonization credits (known as CBios). However, the innovation in such mechanisms lies in the fact that the amount of CBios which an entity may emit in the Brazilian stock market will be linked to the reduction in GHG emissions associated with the production of a given biofuel in comparison to its fossil competitor [2], as investigated in this study.

Several acts and standards have been developed in different countries including rigorous requirements for biofuel producers to confirm the environment-friendly characteristics and ability to effectively reduce GHG emissions in comparison to the corresponding fossil fuels [2]. Towards this goal, the National Biofuel Policy, officially known as RenovaBio Program comes in the form of Law 13.576/2017 for the progress of biofuels in Brazil. Bioenergy production could potentially mitigate GHG emissions and climate change by avoiding the combustion of fossil energy, therefore safeguarding energy security. However, there are issues that need to be considered, including the sustainability of practices and the efficiency of bioenergy systems[3]. The increased attention on bioenergy occurs in conjunction with the global interest in transitioning from large scale dependence upon fossil fuels to the use of renewable energy sources to curb 
GHG emissions [4]. Research evidence suggests that some already available and well-established options with low lifecycle emissions (e.g., sugarcane, and sustainable use of biomass residues) could reduce GHG emissions, but outcomes are site-specific and rely on efficient integrated 'biomass-to-bioenergy systems'[3].

The impact of sugarcane straw removal on economic, environmental, and agronomic factors are well documented and discussed in terms of sugarcane growth and biomass production, nutrient recycling, soil conservation, soil biological attributes, greenhouse gas emissions, weed control and pest infestation [5-9]. Although the retention of sugarcane straw presents several benefits to the soil, there is potential to withdraw part of the straw from the fields to produce bioelectricity and cellulosic ethanol (second generation-2G). However, further studies are needed to demonstrate the sustainability of this practice and the best options for industrial use of this crop residue.

Regardless of considerable potential for increased energy generation from the use of recovered straw, few studies have investigated the impact of straw removal on soil $\mathrm{CO}_{2}-\mathrm{C}$ emissions and additional GHG emissions associated with straw removal and transport operations $[6,10,11]$. In a sugarcane area under 3 years of green mechanized harvesting, [6] showed that around 100\% removal of straw from the soil surface led to an additional emission of $927.7 \mathrm{~kg}$ of $\mathrm{CO}_{2} \mathrm{ha}^{-1}$ to the atmosphere over a 25-day measurement period. In terms of the GHG balance, such additional emissions can annul the benefits of banning the preharvest burning, which is responsible for an estimated net emission $\left(\mathrm{CH}_{4}\right.$ and $\left.\mathrm{N}_{2} \mathrm{O}\right)$ of $941 \mathrm{~kg} \mathrm{CO}_{2}$ eq ha-1 [12].

The hypotheses tested in the present study were: (1) The recovery and transport of large amount of sugarcane straw from fields upon mechanized harvesting without burning may result in additional soil $\mathrm{CO}_{2}$ and other $\mathrm{GHG}$ emissions (soil $\mathrm{N}_{2} \mathrm{O}$ and emissions from diesel combustion), greater than the potential to offset emissions through the use of straw for bioenergy (bioelectricity or $2 \mathrm{G}$ ethanol); (2) Partial removal of sugarcane straw from the soil surface can be a sustainable alternative for its use as bioelectricity source or $2 \mathrm{G}$ ethanol production, taking into account their additional GHG emissions and offset potential. This study was designed to assess the additional $\mathrm{GHG}$ emissions including measurements of short-term soil $\mathrm{CO}_{2}-\mathrm{C}$ emissions as affected by straw removal from the soil in sugarcane areas plus emissions associated with the recovery and transport operations of straw bales up to the factory gate, contrasting with leaving all straw on the soil surface. Specific objective is to contrast the additional emissions of straw recoveredmanagement operations with respective GHG offset potential of straw-based bioenergy production (i.e. electricity generation or $2 \mathrm{G}$ ethanol), based on Brazilian energy matrix.

\section{Materials And Methods}

This study was carried out at a commercial sugar, ethanol and energy production plant located in the region of Ribeirão Preto, Sao Paulo, southern Brazil, where the company performs the removal of straw for bioenergy generation. The results of GHG emissions and offset potential for straw recovery were presented in terms of carbon dioxide equivalents $\left(\mathrm{CO}_{2} \mathrm{eq}\right)$ according to the global warming potentials of 1,28 and 
265 for carbon dioxide $\left(\mathrm{CO}_{2}\right)$, methane $\left(\mathrm{CH}_{4}\right)$ and nitrous oxide $\left(\mathrm{N}_{2} \mathrm{O}\right)$ [13]. In addition, molar ratio of 1 $\mathrm{C}=44 / 12 \mathrm{CO}_{2}$ eq was used to convert $\mathrm{C}$ mass in $\mathrm{CO}_{2}$ eq.

\subsection{Short-term measurements of soil $\mathrm{CO}_{2}-\mathrm{C}$ emissions, soil water content and soil temperature}

The field experiment for measuring soil $\mathrm{CO}_{2}-\mathrm{C}$ emissions was in Serrana, Sao Paulo State, Brazil $\left(21^{\circ} 06^{\prime} \mathrm{S}\right.$ $-47^{\circ} 37^{\prime} \mathrm{W}, 623 \mathrm{~m}$ of altitude). According to the data provided by the agricultural and industrial facility, the sugarcane variety in the experimental area was IACSP 95-5000, planted at $1.5 \mathrm{~m}$ inter-row spacing, and with a first cutting stalk yield of 143 tons $\mathrm{ha}^{-1}$. The field experiment started on August 03, 2016, immediately after the straw removal, in which all operations were carried out within 20 days of mechanized harvest without burning, following the standard procedure of the company. The regional climate is classified as $\mathrm{B}_{2} \mathrm{rB}^{\prime} 4 \mathrm{a}^{\prime}$ by Thornthwaite system [14], indicating a mesothermal region with rainy summers and dry winters. The soil is classified as a Eutroferric Red Latosol (Haplustox, USDA Soil Taxonomy).

Short-term soil $\mathrm{CO}_{2}-\mathrm{C}$ emissions, soil water content (SWC) and soil temperature (12 cm depth) were monitored starting $24 \mathrm{~h}$ after straw removal (August 4th 2016) in different treatment plots where PVC collars were previously inserted into soil (15 replicates per treatment). Measurements were taken 17 days over a 21-day period after straw removal in the morning between 8:00 to 11:00 AM on each sampling day. Soil $\mathrm{CO}_{2}$-C emissions were measured using a portable LI-COR (LI-8100, NE, USA) system which monitors the changes in $\mathrm{CO}_{2}$ concentration inside the chamber by an infrared gas analyzer. The floor chamber has an internal volume of $854.2 \mathrm{~cm}^{3}$ with a circular area of $83.7 \mathrm{~cm}^{2}$. The soil temperature was monitored with a $20 \mathrm{~cm}$ probe (thermistor-based sensor) inserted into the soil near the PVC collars at a depth of $12 \mathrm{~cm}$. This measuring sensor is an integral part of the LI-8100 system. Soil water content (\%) was measured (12 $\mathrm{cm}$ depth) with a portable time domain reflectometer system (HydroSense System, Campbell Scientific, Utah, USA). During the measurement period, rainfall events occurred on August 10 th $(02 \mathrm{~mm}), 15$ th (10mm), 16th (10 mm), 18th (08 mm), 19th (10 mm), 20th $(15 \mathrm{~mm})$ and 23rd (11 mm).

\subsubsection{Field treatments for measuring soil $\mathrm{CO}_{2}-\mathrm{C}$ emissions}

The experiment for measuring soil $\mathrm{CO}_{2}-\mathrm{C}$ emissions comprised of three treatments replicated three times. The treatments consisted of a control ( $T 1)$, which are areas of $12 \times 20$ m plots $\left(\sim 240 \mathrm{~m}^{2}\right)$ where all straw was left on the soil surface after sugarcane harvest without any straw recovery, and two field conditions (T2 and T3 explained below), according to the soil cover observed after the straw management and recovery operation in a commercial sugarcane plantation (Fig. 1).

In areas where straw is managed for recovery, straw from 6 crop rows ( 5 inter-row areas) are collected with each passing of a tractor and heaped in between two crop rows (one inter-row area) to be removed later by baling. After straw was baled and removed, there are still more straw left on the soil surface of the inter-row area where straw was heaped prior to baling than in the control area. This inter-row area where straw was 
accumulated was defined as T2 (line plots of $1.5 \times 20 \mathrm{~m}$ or $30 \mathrm{~m}^{2}$ ). The area of 6 crop rows from which straw was collected has less straw on the soil surface than in the control area, and this area was defined as T3. Overall, in a field where straw was managed and recovered, T2 area occupies approximately $17 \%$ of the field area and T3 area occupies about $83 \%$ of the field area. Therefore, to calculate the $\mathrm{CO}_{2}-\mathrm{C}$ emissions from 1 ha field in response to straw management and recovery, a weighted average emissions per ha was calculated using measured emissions from T2 and T3 area according to the Equation 1:

$$
\mathrm{WAFCO}_{2}=0.83 \mathrm{FCO}_{2} \mathrm{~T} 3+0.17 \mathrm{FCO}_{2} \mathrm{~T}_{2}
$$

Where, $W A F \mathrm{CO}_{2}$ : weighted average $\mathrm{CO}_{2}$ flux; $\mathrm{FCO}_{2} \mathrm{~T} 3$ : $\mathrm{CO}_{2}$ flux from T3 area; and $\mathrm{FCO}_{2} \mathrm{~T}_{2}$ : $\mathrm{CO}_{2}$ flux from T2 area. In each treatment (3 replicates), $15 \mathrm{PVC}$ collars were used for measurements of soil $\mathrm{CO}_{2}-\mathrm{C}$ emissions. In general, straw management and recovery operation resulted in a removal of $27 \%$ of sugarcane straw for bioenergy generation (explained below).

\subsubsection{Statistical analysis}

Data related to $\mathrm{CO}_{2}-\mathrm{C}$ emissions, soil temperature and soil water content (SWC) were analyzed using a completely randomized experimental design with three treatments and three replicates per treatment (defined in section 2.1.1) and repeated measurements in time. For the analyzes, the mixed-model procedure of SAS statistical software was used [SAS Institute Inc., Cary, North Caroline]. When statistically significant $(P<0.05)$, the means were compared by the Tukey's test at a significance level of $5 \%$. The variables $\left(\mathrm{CO}_{2}-\mathrm{C}\right.$, soil temperature and soil water content) were also analyzed by linear correlation, testing if correlation coefficient is statistically different from zero $(P<0.05)$.

\subsection{Soil analysis, quantification of post-harvest straw and estimated $\mathrm{N}_{2} \mathrm{O}$ emissions}

Soil samples were collected to a $0.20-\mathrm{m}$ depth after measurements of soil $\mathrm{CO}_{2}-\mathrm{C}$ emissions. To obtain $1 \mathrm{~kg}$ of soil, 12 single samples were collected from the experimental area, and soil physical-chemical characteristics such as $\mathrm{pH}$, soil organic matter (SOM) and soil texture were analyzed (Table 1). The samples were dried and sieved through a $2 \mathrm{~mm}$ mesh prior to analysis. These analyzes include determination of SOM content by oxidation with sulphuric acid [15]. 
Table 1

Soil chemical and physical characterization of the experimental area $(0-20 \mathrm{~cm}$ depth).

\begin{tabular}{|c|c|c|c|c|c|c|c|c|c|c|}
\hline $\mathrm{pH}$ & SOM & $\mathbf{P}$ & $\mathrm{Ca}$ & $\mathbf{M g}$ & $\mathrm{K}$ & CEC & BS & Clay & Silt & Sand \\
\hline & $g \mathrm{dm}^{-3}$ & $\mathrm{mg} \mathrm{dm} \mathrm{m}^{-3}$ & \multicolumn{2}{|c|}{$\mathrm{mmol}_{\mathrm{C}} \mathrm{dm}^{-3}$} & & & $\%$ & $\mathrm{~g} \mathrm{~kg}^{-1}$ & & \\
\hline 7 & 31 & 10 & 31 & 10 & 6.4 & 83 & 58 & 52 & 18 & 30 \\
\hline \multicolumn{11}{|c|}{$N=10 ; 0-20 \mathrm{~cm}$ depth. Clay, Silt and Sand. } \\
\hline \multicolumn{11}{|c|}{$\begin{array}{l}\text { pH, hydrogenic potential }\left(\mathrm{CaCl}_{2}\right) \text {; } \mathrm{SOM} \text {, Soil organic matter; } \mathrm{P} \text {, available phosphorus; } \mathrm{Ca} \text {, calcium; } \mathrm{Mg} \text {, } \\
\text { magnesium; } \mathrm{K} \text {, potassium; } \mathrm{CEC} \text {, Cation exchange capacity; } \mathrm{BS} \text {, Base saturation. }\end{array}$} \\
\hline
\end{tabular}

The amount of straw deposited on the soil surface after sugarcane green mechanized harvesting, as well as straw management and recovery operation were determined by collecting samples using a metallic frame of $0.64 \mathrm{~m}^{2}(0.8 \times 0.8 \mathrm{~m})$ in each of the three treatments $(n=5)$. The samples were oven dried for 24 hs at $105^{\circ} \mathrm{C}$ until reaching constant weight and then weighed [16] which resulted in: $25,819 \mathrm{~kg} \mathrm{DM} \mathrm{ha}^{-1}$ for $\mathrm{T} 1 ; 44,303 \mathrm{~kg} \mathrm{DM} \mathrm{ha}^{-1}$ for T2 and 18,927 $\mathrm{kg} \mathrm{DM} \mathrm{ha}^{-1}$ for T3. The average amount of straw removed from fields after straw management and recovery operation was calculated as the difference of straw mulch dry matter left on soil surface between T1 and T3 (T3-T1) which resulted in 6,89 $\mathrm{kg} \mathrm{DM} \mathrm{ha}^{-1}$ (or 27\% of the total straw in the control area).

Crop residues such as sugarcane straw when returned to the soil after harvest are considered as a direct source of $\mathrm{N}_{2} \mathrm{O}$ from agricultural soils, and an average $\mathrm{N}_{2} \mathrm{O}-\mathrm{N}$ emission factor of $1 \%$ for $\mathrm{N}$ returned to soil from crop residues is recommended for estimating the direct $\mathrm{N}_{2} \mathrm{O}$ emissions from crop residue decomposition [17].

Amount of total $\mathrm{N}$ returned to soil from sugarcane crop residues was estimated applying green tops and dry leaves content of $65 \%$ and $35 \%$, respectively of the total $N$ present in sugarcane crop residues $[18,19]$, which translate to an average rate of 7.5 and $3.4 \mathrm{~g} \mathrm{~N} \mathrm{~kg}^{-1}$ of dry matter, respectively. Applying a rate of $20 \%$ of straw $\mathrm{N}$ content available for $\mathrm{N}_{2} \mathrm{O}$ emission each year, we estimate an average amount of $31.3 \mathrm{~kg} \mathrm{~N}$ year $^{-1}$ in T1 when leaving all straw in the field without management $\left(25,819 \mathrm{~kg} \mathrm{DM} \mathrm{ha}^{-1}\right)$, and an average amount of $23.0 \mathrm{~kg} \mathrm{~N}$ year $^{-1}$ in T3 $\left(18,927 \mathrm{~kg} \mathrm{DM} \mathrm{ha}^{-1}\right)$, after recovering $6,89 \mathrm{~kg} \mathrm{DM} \mathrm{ha}^{-1}$. To evaluate the impact of $\mathrm{N}_{2} \mathrm{O}$ emissions from removing $6,89 \mathrm{~kg}$ DM of straw we need to compare the potential $\mathrm{N}_{2} \mathrm{O}$ emissions from T1 with T3.

In order to derive an $\mathrm{N}_{2} \mathrm{O}-\mathrm{N}$ emission factor for crop residue removal, carried out field experiments were carried out in commercial sugarcane areas in clay soils (64\% clay content) [20][27], similar to the experimental site of this study ( $52 \%$ clay; Table 1 ) and, reported cumulative $\mathrm{N}_{2} \mathrm{O}-\mathrm{N}$ emissions of $1.45 \mathrm{~kg}$ $\mathrm{N}_{2} \mathrm{O}-\mathrm{N} \mathrm{ha}{ }^{-1}$ associated with the maintenance of 15 ton DM of straw ha- ${ }^{-1}$ and without $\mathrm{N}$ fertilizer application over a 270-days period. Furthermore, the authors showed that $\mathrm{N}_{2} \mathrm{O}-\mathrm{N}$ emissions decreased to $0.91 \mathrm{~kg} \mathrm{~N}_{2} \mathrm{O}-\mathrm{N} \mathrm{ha}^{-1}$ for the management and recovery of total amount of straw from the soil surface without $\mathrm{N}$ fertilizer. Considering the similarity with soils and climate conditions of this study, we applied the 
same accumulated $\mathrm{N}_{2} \mathrm{O}-\mathrm{N}$ emissions [20] to be compared with the results derived using the IPCC methodology [17]. Evaluating GHG emissions in response to sugarcane straw removal, authors observed no net $\mathrm{CH}_{4}$ emissions [21], and thus, $\mathrm{CH}_{4}$ emissions were not considered in our study.

\subsection{Estimation of greenhouse gas emissions from fossil fuel used in the recovery and transport of straw}

In addition to industrial plant, further investments on tractors, trucks and other heavy machines are required in the management and recovery of sugarcane straw after green mechanized harvest. For this experiment, the data collected and analysed were: Truck carry capacity of approximately 70 bales per trip; bales weighing on average of $350 \mathrm{~kg}$ bale $\mathrm{e}^{-1}$ and $24,500 \mathrm{~kg}$ of straw transported per trip, with a straw moisture content of around 6 to $10 \%$.

The technical parameters for mechanized operations considered in the straw management and recovery operation and the transport of straw until the biorefinery gate are presented in Table 2. The fossil fuel typically used for sugarcane production systems is diesel oil, consumed mostly during the agricultural operations by machinery, tractors, and trucks [12]. In our study, the diesel consumption related to the final use of sugarcane straw was measured according to all field operations performed (Table 2.). 
Table 2

Technical parameters of diesel consumption in mechanized operations for the amount of sugarcane straw recovered of 6.89 tons $^{-1} \mathrm{ha}^{-1}$ (dry matter-basis).

\begin{tabular}{|c|c|c|c|c|c|}
\hline Operation & Equipment & $\begin{array}{l}\text { Horse } \\
\text { Power (HP) }\end{array}$ & $\begin{array}{l}\text { Consumption } \\
(\mathrm{L} \text { diesel } \\
\left.\mathrm{ha}^{-1}\right)\end{array}$ & $\begin{array}{l}\text { Operation } \\
\text { income }\left(\mathrm{ha} \mathrm{h}^{-1}\right)\end{array}$ & $\begin{array}{l}\text { L diesel ton } \\
\text { of straw }\end{array}$ \\
\hline (1) Straw heaping & Tractor & 110 & 7.00 & 8.2 & 0.9 \\
\hline (2) Baling & Tractor & 210 & 20.00 & 5.5 & 3.0 \\
\hline (3) Bales picking & Tractor & 210 & 13.7 & 5.4 & 3.0 \\
\hline (4) Bales loading & Tractor & 130 & 4.5 & 8.0 & 2.1 \\
\hline *(5) Bales transport & Truck & - & $1.4 \mathrm{~km} \mathrm{~L}^{-1}$ & - & $\begin{array}{l}0.466 \\
(0.233 \times 2)\end{array}$ \\
\hline (6) Bales unloading & Loader & 130 & $4.3\left(\mathrm{~L} \mathrm{~h}^{-1}\right)$ & - & 0.122 \\
\hline (7) Crusher feeding & Loader & 130 & $3.1\left(\mathrm{~L} \mathrm{~h}^{-1}\right)$ & - & 0.257 \\
\hline $\begin{array}{l}\text { Total (L diesel } \\
\text { ton }^{-1} \text { straw) }\end{array}$ & & & & & 9.895 \\
\hline $\begin{array}{l}\text { Total }(L \text { diesel } \\
\left.h^{-1}\right)\end{array}$ & & & & & 68.2 \\
\hline \multicolumn{6}{|c|}{$\begin{array}{l}{ }^{*} \text { Truck carry capacity is approximately } 70 \text { bales per trip. Bales weight }=\text { average } 350 \mathrm{~kg}=24,500 \mathrm{~kg} \text { per } \\
\text { trip. }\end{array}$} \\
\hline${ }^{\star \star}$ Distance of the exp & rimental are & until the indus & ial straw proce & ing $=8 \mathrm{~km}=16 \mathrm{kr}$ & round trip. \\
\hline
\end{tabular}

Estimates of $\mathrm{GHG}$ emissions related to the use of fossil fuel for straw recovery in this study assumed $\mathrm{CO}_{2}$, $\mathrm{CH}_{4}$ and $\mathrm{N}_{2} \mathrm{O}$ gases [22]. The emission factors applied were those suggested by Air Pollution Control Program for Auto Engines)/CETESB-Brazil [23], in association with IBAMA (Brazilian Institute of the Environment), considering the types of fuel and vehicles. To calculate these emission factors, vehicles were considered as off-road and machinery, with 74,100 $\mathrm{kg} \mathrm{CO}_{2} \mathrm{TJ}^{-1}$ ( $\mathrm{TJ}=$ Terajoule), $4.15 \mathrm{~kg} \mathrm{CH}_{4} \mathrm{TJ}^{-1}$ and 28.6 $\mathrm{kg} \mathrm{N}_{2} \mathrm{O} \mathrm{TJ}^{-1}$, respectively [24]. The $\mathrm{GHG}$ emissions related to diesel extraction and distribution were considered as $3.87 \mathrm{~g} \mathrm{C} \mathrm{MJ}^{-1}$ per liter of fuel [25].

\subsection{Quantification of energy and cellulosic ethanol (2G) production from straw recovered}

The use of sugarcane bagasse as a fuel for combined heat and power (CHP) systems to meet energy needs of the mills for bioenergy generation is a common practice in Brazilian sugarcane industry [26]. In 
this study, we present an additional energy generation potential of sugarcane straw recovered after green mechanized harvesting as per the technology used by the company. According to the information from the company's industrial sector, the straw used for energy generation is added to the sugarcane bagasse at a proportion of 5 to $7 \%$ of the volume, presenting a potential value for electricity generation of approximately $0.6 \mathrm{MWh}$ ton $^{-1} \mathrm{DM}$, with humidity between 6 and $10 \%$ and the technology being used is high pressure boiler/condensation and steam extraction turbine.

Analysing the use of sugarcane straw for power generation, some authors reported a higher heating value of cane straw of $17.1 \mathrm{MJ} \mathrm{kg}^{-1}$ (DM) and lower heating value of $12.15 \mathrm{MJ} \mathrm{kg}^{-1}$, without considering of the losses through the process [27]. With respect to industrial productivity, the premise to produce $240 \mathrm{~L}$ ethanol ton ${ }^{-1} \mathrm{LM}$ (lignocellulosic material on dry basis) in the short-term was reasonably conservative by companies[28]. For some companies, it is already feasible to reach $300 \mathrm{~L}$ ethanol $\operatorname{ton}^{-1} \mathrm{LM}$, or even $350 \mathrm{~L}$ ethanol ton ${ }^{-1} \mathrm{LM}$ in the long-term. On the other hand, electric power demand for $2 \mathrm{G}$ process is depicted as $48 \mathrm{kWh}$ ton $^{-1} \mathrm{LM}$ over a short, medium, and long-term basis. However, the energy demand for $2 \mathrm{G}$ ethanol production from the straw can be supplied by the residual material (residual cellulignin) from the $2 \mathrm{G}$ process, and thus there is no need to burn additional straw to supply this energy demand [28].

Based on data from parameters for vehicle emissions in Brazil, an emission factor (EF) of $1.750 \mathrm{~kg} \mathrm{CO}{ }_{2} \mathrm{eq}$ $\mathrm{L}^{-1}$ of hydrated ethanol should be applied for a vehicle year 2010, flex (ethanol or gasoline), using ethanol, with efficiency of $8.2 \mathrm{~km} \mathrm{~L}^{-1}$, considering emissions of $\mathrm{CO}_{2}\left(207 \mathrm{~g} \mathrm{~km}^{-1}\right), \mathrm{CH}_{4}\left(0.053 \mathrm{~g} \mathrm{~km}^{-1}\right)$ and $\mathrm{N}_{2} \mathrm{O}$ $\left(0.017 \mathrm{~g} \mathrm{~km}^{-1}\right)$ [23]. The $\mathrm{CO}_{2}$ emitted through the combustion of ethanol in the vehicle motor is reabsorbed by the sugarcane plants, rendering the balance practically zero [29] and, consequently should not be accounted for in the $\mathrm{CO}_{2}$ balance. To estimate the avoided $\mathrm{GHG}$ emissions when using renewable $2 \mathrm{G}$ ethanol from straw replacing gasoline, we considered the use of light vehicle, with efficiency of $10.8 \mathrm{~km} \mathrm{~L}^{-1}$ of gasoline [23] with EF of $2.312 \mathrm{~kg} \mathrm{CO}_{2} \mathrm{eq} \mathrm{L}^{-1}\left(207 \mathrm{~g} \mathrm{CO}_{2} \mathrm{~km}^{-1}, 0.009 \mathrm{~g} \mathrm{CH}_{4} \mathrm{~km}^{-1}\right.$ and $0.023 \mathrm{~g} \mathrm{~N}_{2} \mathrm{O} \mathrm{km}^{-1}$ ). Therefore, when replacing 1 liter of fossil gasoline per 1 liter of hydrated ethanol, an avoided emission of $2.26 \mathrm{~kg} \mathrm{CO}{ }_{2}$ eq considering only $\mathrm{CH}_{4}$ and $\mathrm{N}_{2} \mathrm{O}$ emission from ethanol was assumed in this study when considering $2 \mathrm{G}$ ethanol production from sugarcane straw.

\section{5. $\mathrm{CO}_{2}$ emission factors for electric energy production in Brazil}

The $\mathrm{CO}_{2}$ emission factors of electric energy production used in life-cycle inventories in Brazil estimate the amount of $\mathrm{CO}_{2}$ associated with the generation of a particular type or source of electric energy. These emission factors are calculated by the average of emissions sources, considering of all the plants that are generating energy, and not only those that are working at the moment [30], presenting emission factors in terms of ton $\mathrm{CO}_{2}$ eq $\mathrm{MWh}^{-1}$.

The $\mathrm{CO}_{2}$ emission factors calculated according to the methodological approach "Tool to calculate the emission factor for an electricity system, version 04.0 and earlier" approved by the Clean Development 
Mechanism (CDM), Executive Board are intended to estimate the contribution, in terms of $\mathrm{CO}_{2}$ emission reductions, from a project that generates electricity for the grid [30]. Briefly, the interconnected system CDM emission factor is a combination of the operating margin emission factor, which reflects the intensity of $\mathrm{CO}_{2}$ emissions of the energy dispatched at the margin, with the build margin emission factor that reflects the intensity of $\mathrm{CO}_{2}$ emissions from the last plants built [30].

The emission factors (ton $\mathrm{CO}_{2} \mathrm{MWh}^{-1}$ ) for electricity generation in Brazil presented annual average values of $0.0740 ; 0.0927 ; 0.0817 ; 0.1244 ; 0.1355 ; 0.0960 ; 0.0653$ and 0.0292 for the years $2018,2017,2016,2015$, 2014, 2013, 2012 and 2011, respectively [30]. However, in this study, the offset potential for straw recovered displacing energy produced by Brazilian energy matrix was calculated based on the EF of 0.1370 ton $\mathrm{CO}_{2}$ $\mathrm{MWh}^{-1}$, accounting emissions from plants built and energy generation at the margin [30].

\section{Results And Discussion}

\subsection{Short-term soil $\mathrm{CO}_{2}-\mathrm{C}$ emissions, soil water content and soil temperature}

Figure 2a presents the temporal soil $\mathrm{CO}_{2}-\mathrm{C}$ emissions comparing the management of recovering part of straw (T3; leaving 18.9 ton $\mathrm{DM} \mathrm{ha}^{-1}$ ), with the management of keeping all straw on the soil surface without removal (T1; leaving 25.8 ton $\mathrm{DM} \mathrm{ha}^{-1}$ ), resulting in a straw removal rate of 6.89 ton $\mathrm{DM} \mathrm{ha}^{-1}$. Significant difference $(P<0.05)$ among the treatments was observed only on day 20 , showing that agricultural operations to recover around $27 \%$ of straw may not significantly impact the temporal soil $\mathrm{CO}_{2}-\mathrm{C}$ emissions during the experiment measurements.

Highest temporal emissions were observed in T2, except for day $20(P<0.05)$. This could be explained by the straw management and accumulation of large amount of straw between two crop lines (inter-row), which could promote higher soil aeration, higher $\mathrm{O}_{2}$ availability for microorganism's activity and higher $\mathrm{C}$ accessibility (straw carbon) to be decomposed through mineralization process. In contrast, keeping sugarcane straw on the soil surface without management led to a lower soil $\mathrm{CO}_{2}-\mathrm{C}$ emission [6], probably due to higher soil bulk density and lower soil aeration [31], showing that in a condition where soil and straw were managed, the mineralization of SOM (soil organic matter) increased significantly with higher aeration, thus supporting the findings observed in T2.

The impacts of straw management on soil temperature can be observed in Figure $2 \mathrm{~b}$, when comparing T1 (straw maintained), with T3 (27\% of straw recovery). There was significant difference between these two treatments only on days 07 and 09 ( $P<0.05)$, in which soil temperature was higher in T3, showing that recovering $27 \%$ of straw had a slight impact on soil temperature.

The higher amount of straw accumulated in T2 (44.3 tons DM ha ${ }^{-1}$ ) could explain this higher soil water content (SWC), with straw mulching contributing to soil protection against evaporation. Moreover, when 
comparing the management of removing $27 \%$ of straw (T3) with the management of keeping all straw on the soil surface (T1), during the dry period, there was no significant difference for soil water content ( $P$ > 0.05), showing that higher amount of straw could keep higher available soil water content.

In terms of accumulated short-term soil $\mathrm{CO}_{2}-\mathrm{C}$ emissions (Fig. 2d), lower emissions were observed in $\mathrm{T} 1$ with $788 \mathrm{~kg} \mathrm{CO}_{2}-\mathrm{C}$ or $2,889 \mathrm{~kg} \mathrm{CO}_{2} \mathrm{ha}^{-1}$. However, comparison of the accumulated soil $\mathrm{CO}_{2}-\mathrm{C}$ emissions in the management of recovering $27 \%$ of straw $\left(\mathrm{WAFCO}_{2}, 963 \mathrm{~kg} \mathrm{CO}_{2}-\mathrm{C}\right.$ or $\left.3,531 \mathrm{~kg} \mathrm{CO}_{2} \mathrm{ha}^{-1}\right)$ with the management of keeping all straw on the soil surface ( $\mathrm{T} 1$ ), did not indicate significant difference between the two managements, showing that recovering $27 \%$ of straw in the experiment conditions did not impact the accumulated short-term soil $\mathrm{CO}_{2}-\mathrm{C}$ emissions. Therefore, the impact of straw removal $(27 \%$ or 6.89 ton $\mathrm{DM} \mathrm{ha}^{-1}$ ) on accumulated soil $\mathrm{CO}_{2}-\mathrm{C}$ emission over 21 days $\left(\mathrm{WAFCO}_{2}\right)$ was $175.5 \mathrm{~kg} \mathrm{CO}_{2}-\mathrm{C} \mathrm{ha}^{-1}$ or 643.5 $\mathrm{kg} \mathrm{CO}_{2}$ ha $^{-1}$, which is equivalent to $25.5 \mathrm{~kg} \mathrm{CO}_{2}-\mathrm{C}_{\text {ton }}^{-1}$ or $93.4 \mathrm{~kg} \mathrm{CO}_{2}$ ton $^{-1}$ of straw (Fig. 3). It is important to note that the additional short-term soil $\mathrm{CO}_{2}-\mathrm{C}$ emissions in sugarcane areas may be higher soon after straw management, and then these emissions tend to stabilize to similar levels compared with emissions from areas with no straw management, as observed for T1 and T3 at the end of the experimental period. Exploring the GHG responses to sugarcane straw removal, a rate of 6 ton DM of straw $\mathrm{ha}^{-1}$ resulted in a total $\mathrm{CO}_{2}-\mathrm{C}$ emissions of $82.2 \mathrm{~g} \mathrm{~m}^{-2}$ or $3,014 \mathrm{~kg} \mathrm{CO}_{2} \mathrm{ha}^{-1}$ in a period of 180 days [21]. In a scenario with straw removal and possible SOC losses, we need to consider no-tillage operations during sugarcane crop renovation, mainly if it is combined with other best management practices, such as reduced tillage accompanied with vinasse and filter cake application, which could replace the SOC losses after residue removal [6, 32, 33].

\subsection{Emissions from fossil fuel used to recover and transport of straw}

Specific management options practiced by sugarcane mills for straw recovery systems certainly have distinct impact on the economic and technical parameters. Taking into account of all additional mechanized field operations for straw recovery and their respective machinery use and diesel consumption (Table 2), the total amount of diesel consumed to recover 1 ton of straw under the experimental parameters was $9.9 \mathrm{~L} \mathrm{ton}^{-1}$ of straw or $68.2 \mathrm{~L}$ of diesel ha ${ }^{-1}$ (6.89 ton ha-1, dry matter-basis), resulting in an emissions of $31.6 \mathrm{~kg} \mathrm{CO}_{2}$ eq ton ${ }^{-1}$ of straw or $217.1 \mathrm{~kg} \mathrm{CO}_{2}$ eq ha ${ }^{-1}$ (Fig. 3). These emissions from mechanized operations to recover straw is considered as additional emissions compared with the management of leaving all straw in the field and should be included in assessing the GHG mitigation potential of straw for bioenergy generation.

\subsection{Estimation of $\mathrm{N}_{2} \mathrm{O}$ emissions derived from post-harvest sugarcane straw}

Applying default methodology for $\mathrm{N}_{2} \mathrm{O}$ emissions [17] and straw amount measured in the experiment, leaving all straw on the soil surface without management (T1) led to an estimated $\mathrm{N}_{2} \mathrm{O}$ emissions of 159.7 
$\mathrm{kg} \mathrm{CO}_{2}$ eq ha ${ }^{-1}$. On the other hand, recovering 6.89 tons $\mathrm{DM}$ of straw ha ${ }^{-1}$, resulted in an estimated $\mathrm{N}_{2} \mathrm{O}$ emissions of $117.3 \mathrm{~kg} \mathrm{CO}_{2}$ eq ha-1. Thus, comparing the practice of leaving all straw on the soil surface against the practice of recovering $27 \%$ of straw (6.89 ton $\mathrm{DM} \mathrm{ha}^{-1}$ ), the estimations showed an avoided emission of $42.4 \mathrm{~kg} \mathrm{CO}_{2}$ eq ha ${ }^{-1}\left(\mathrm{~N}_{2} \mathrm{O}-\mathrm{N}\right.$, Fig. 3).

Contrasting the results estimated here by other methodology [17], some authors reported higher accumulated $\mathrm{N}_{2} \mathrm{O}$ emissions from sugarcane straw left on soil ( 15 ton DM ha- ${ }^{-1}$ ), with $2.28 \mathrm{~kg} \mathrm{~N}_{2} \mathrm{O} \mathrm{ha}{ }^{-1}$ or $604.2 \mathrm{~kg} \mathrm{CO}_{2}$ eq ha ${ }^{-1}$ over 270 days-period [20], which was used in our GHG balance for the potential of straw for bioelectricity or $2 \mathrm{G}$ ethanol production (Fig. 3). Besides that, the same authors showed that $\mathrm{N}_{2} \mathrm{O}$ emissions were reduced to $1.43 \mathrm{~kg} \mathrm{~N}_{2} \mathrm{O} \mathrm{ha}^{-1}$ or $379 \mathrm{~kg} \mathrm{CO}_{2}$ eq ha-1 $(-37 \%)$ upon removal of all straw from the soil surface. Lower $\mathrm{N}_{2} \mathrm{O}$ emissions induced by straw removal were also reported by several other studies conducted in Brazil [21, 34, 35].

Compared with the management to recover sugarcane straw from the soil surface for multiple uses, leaving sugarcane straw on the soil surface can lead to higher $\mathrm{N}_{2} \mathrm{O}$ emissions, which would strongly influence the extent to which biofuels derived from straw decrease their GHG emissions relative to fossil fuels [36, 37]. Additionally, irrespective of $\mathrm{N}$ fertilizer application, the retention of sugarcane crop residue increases $\mathrm{N}_{2} \mathrm{O}$ emissions [20], being a catalyst for increased soil microbial activity soil $\mathrm{N}_{2} \mathrm{O}$ flux [38].

\subsection{Potential for straw-based bioenergy and GHG balance of energy or cellulosic ethanol production}

With 6.89 ton of straw DM ha-1 recovered, it is possible to generate $4.1 \mathrm{MWh} \mathrm{ha}^{-1}$ electricity, which means that for each ton of recovered sugarcane straw, considering the emission factor from new projects and energy generation intensity [23] from Brazilian energy matrix (Base year 2018, 0.1370 ton $\mathrm{CO}_{2} \mathrm{MWh}^{-1}$ ), it is likely to have an avoided GHG emissions of $81.5 \mathrm{~kg} \mathrm{CO}_{2} \mathrm{eq} \mathrm{ton}^{-1} \mathrm{DM}$ or $562 \mathrm{~kg} \mathrm{CO}_{2} \mathrm{eq} \mathrm{ha}^{-1}$ (Fig. 3). By using the lower heating value (12.15 $\left.\mathrm{MJ} \mathrm{kg}^{-1} \mathrm{DM}\right)$ for sugarcane straw [27], the surplus energy associated with 6,89 ton $\mathrm{DM} \mathrm{ha}^{-1}$ of straw could encompass a technical potential of 83,737.8 $\mathrm{MJ} \mathrm{ha}^{-1}$ or $23.26 \mathrm{MWh}$ $\mathrm{ha}^{-1}(1 \mathrm{MJ}=0.000277778 \mathrm{KWh}$ ), equivalent to an avoided GHG emissions (based on Brazilian matrix) of $3,186.6 \mathrm{~kg} \mathrm{CO}_{2} \mathrm{ha}^{-1}$. Therefore, the efficiency rate of energy transformation (i.e., industrial process) of sugarcane straw under our experimental conditions is still lower ( 18\%) and, should be improved for a better sustainability of the process.

The RenovaBio Program presents itself as a promising and innovative policy in many aspects (biofuels demand planning and boosting energy security in Brazil), which every single biorefinery in the country will pursue the production of biofuels with an ever-higher environmental responsibility [2]. The characteristics of each country's energy matrix, based on fossil fuels or in renewable sources, as found in Brazil [30] will determine the potential for each country to develop and use straw-based bioenergy sources to reach a lowcarbon energy matrix. 
The $2 \mathrm{G}$ ethanol produced from lignocellulosic biomass $(\mathrm{LM})$ has been considered as the biofuel with the greatest potential to replace fossil fuels $[39,40]$. Based on our experimental results, with the production potential of $240 \mathrm{~L} 2 \mathrm{G}$ ethanol ton ${ }^{-1} \mathrm{LM}$ [26], it would be possible to produce an additional of 1,654 L of ethanol ha-1 (6.89 ton DM straw ha-1), which could promote an avoided GHG emissions of $2.26 \mathrm{~kg} \mathrm{CO}_{2}$ eq $\mathrm{L}^{-1}$ of $2 \mathrm{G}$ ethanol by replacing 1 liter of gasoline or $3,738 \mathrm{~kg} \mathrm{CO}_{2}$ eq ha-1 considering only $\mathrm{CH}_{4}$ and $\mathrm{N}_{2} \mathrm{O}$ emissions from $2 \mathrm{G}$ ethanol combustion (Fig. 3).

Taking into account of all mechanized operations to recover around $27 \%$ of sugarcane straw, the total additional $\mathrm{GHG}$ emissions, considering the main emission sources (i.e., additional soil $\mathrm{CO}_{2}-\mathrm{C}$, diesel use and $\mathrm{N}_{2} \mathrm{O}$ from straw), contrasting with leaving all straw on the soil surface was estimated at $1,465 \mathrm{~kg}$ $\mathrm{CO}_{2}$ eq ha-1 (6.89 ton DM ha-1), resulting an emission factor of $212.6 \mathrm{~kg} \mathrm{CO}_{2}$ eq ton ${ }^{-1}$ of straw recovered. With an avoided $\mathrm{N}_{2} \mathrm{O}$ emissions of $42 \mathrm{~kg} \mathrm{CO}_{2} \mathrm{eq} \mathrm{ha}^{-1}$, compared with higher $\mathrm{N}_{2} \mathrm{O}$ emissions with leaving all straw on soil, $27 \%$ of sugarcane straw removal would therefore result in a total additional emissions of $1,422 \mathrm{~kg} \mathrm{CO}_{2}$ eq ha-1 (Fig. 3).

Applying the parameters cited in this study for electricity or $2 \mathrm{G}$ ethanol production, our results for their respective GHG balance (emissions and offset potential) showed that, straw-based electricity would result in an additional GHG emissions of (+) $860 \mathrm{~kg} \mathrm{CO}_{2}$ eq ha ${ }^{-1}$ (Fig. 3), which could not be a sustainable route for bioenergy production. In contrast, applying the same parameters for $2 \mathrm{G}$ ethanol production replacing gasoline, an avoided GHG emission of (-) 2,316 kg CO${ }_{2} \mathrm{eq} \mathrm{ha}^{-1}$ could be achieved, showing that the route of $2 \mathrm{G}$ ethanol production could be the best strategy to use sugarcane straw as a by-product to reduce $\mathrm{GHG}$ emissions from the agricultural sector, offsetting emissions from fossil fuel and contributing to mitigate global climate change using a renewable bioenergy source.

The results from this research can support deriving environmental indicators to assess the sustainability of $2 \mathrm{G}$ ethanol by regulatory and certifying bodies, such as the CARB (California Air Resources Board) and the most recent State Program "RenovaBio", whose objective is to stimulate the efficiency of the biofuels industry, in the agricultural and industrial sectors, with an emphasis on total energy demand and the mitigation of GHG emissions (lower C intensity) associated with each stage of the life cycle of bioenergy production.

\section{Conclusions}

Bioelectricity and cellulosic ethanol production using sugarcane straw recovered may not be a sustainable management strategy to mitigate GHG emissions when considering the associated impacts on sugarcanecultivated soils and related additional emissions from soil and straw recovering operations. The main additional GHG sources from straw management and agricultural processes include $\mathrm{soil}^{\mathrm{CO}_{2}}$-C emissions, soil $\mathrm{N}_{2} \mathrm{O}$ emissions and emissions from mechanized field operations (diesel use), which should be accounted for deployment of new sugarcane bioenergy projects using straw as a raw material. 
The route of recovering around $27 \%$ of sugarcane straw from the soil surface through bale system for bioelectricity production using technical parameters and industrial efficiency rate of this study, could not be a sustainable option because the additional GHG emissions from these processes can be higher than its potential to offset generated emissions, based on the emission factor of Brazilian energy matrix. On the other hand, using the same parameters for straw recovery at the first cutting cycle in a clay soil, the option of producing ethanol $2 \mathrm{G}$ with around $27 \%$ of the total sugarcane straw recovered ( 6.89 ton dry matter $\left.\mathrm{ha}^{-1}\right)$, could offset greenhouse gas emissions once replacing fossil gasoline, which can be an option to contribute for a better sustainability of sugarcane straw recovery, supporting renewable and sustainable bioenergy systems, and for reducing the impact of Global Climate Change.

\section{Declarations}

\section{Acknowledgments}

We are grateful to SãoPaulo State University (UNESP), Department of Engineering and Exact Sciences, Via de Acesso Prof. Paulo Donato Castellane s/n, Jaboticabal, SP, Brazil, for financial support.

\section{Funding}

No funding was received for this work.

\section{Availability of data and materials}

All base data and statistical analysis used for this research are available.

\section{Authors 'contributions}

We attest that all authors contributed significantly to the creation of this manuscript, each having fulfilled criteria as established by the journal.

\section{Ethics approval and consent to participate}

Written consent to publish potentially identifying information, such as details or the case and photographs, was obtained from the patient(s) or their legal guardian(s).

\section{Consent for publication}

We confirm that we have given due consideration to the protection of intellectual property associated with this work and that there are no impediments to publication, including the timing of publication, with respect to intellectual property. In so doing we confirm that we have followed the regulations of our institutions concerning intellectual property.

\section{Competing interests}

All authors declare there is no conflict of interest exists. 


\section{References}

1. R. de Oliveira Bordonal, R. Lal, D. Alves Aguiar, E.B. de Figueiredo, L. Ito Perillo, M. Adami, B.F. Theodor Rudorff, N. La Scala, Greenhouse gas balance from cultivation and direct land use change of recently established sugarcane (Saccharum officinarum) plantation in south-central Brazil, Renewable and Sustainable Energy Reviews 52 (2015) 547-556.

2. B.C. Klein, M.F. Chagas, M.D.B. Watanabe, A. Bonomi, R. Maciel, Low carbon biofuels and the New Brazilian National Biofuel Policy (RenovaBio): A case study for sugarcane mills and integrated sugarcane-microalgae biorefineries, Renewable \& Sustainable Energy Reviews 115 (2019).

3. IPCC, Climate Change 2014: Synthesis Report. Contribution of Working Groups I, II and III to the Fifth Assessment Report of the Intergovernmental Panel on Climate Change [Core Writing Team, R.K. Pachauri and L.A. Meyer (eds.)]. IPCC, Geneva, Switzerland, 151 pp., Cambridge University Press, Cambridge, United Kingdom and New York, NY, USA, 2014, p. 32.

4. L.L. Benites Lazaro, L.L. Giatti, J.A. Puppim de Oliveira, Water-energy-food nexus approach at the core of businesses - How businesses in the bioenergy sector in Brazil are responding to integrated challenges?, Journal of Cleaner Production 303 (2021) 127102.

5. T.D. Cardoso, O. Cavalett, M.F. Chagas, E.R. de Morais, J.L.N. Carvalho, H.C.J. Franco, M.V. Galdos, F.V. Scarpare, O.A. Braunbeck, L.A.B. Cortez, A. Bonomi, Technical and economic assessment of trash recovery in the sugarcane bioenergy production system, Scientia Agricola 70(5) (2013) 353-360.

6. E.B. de Figueiredo, A.R. Panosso, D.C. Reicosky, N. La Scala, Short-term $\mathrm{CO}_{2}-\mathrm{C}$ emissions from soil prior to sugarcane (Saccharum spp.) replanting in southern Brazil, Global Change Biology Bioenergy 7(2) (2015) 316-327.

7. D.T. De Paula, M.V. Martins, V.L.D. Farias, D.S. Siqueira, Clay and phosphorus losses by erosion in oxisol with sugarcane residues, Engenharia Agricola 36(6) (2016) 1063-1072.

8. L.S. Satiro, M.R. Cherubin, J.L. Safanelli, I.P. Lisboa, P.R. da Rocha, C.E.P. Cerri, C.C. Cerri, Sugarcane straw removal effects on Ultisols and Oxisols in south-central Brazil, Geoderma Regional 11 (2017) 8695.

9. M.R. Cherubin, D.M.D. Oliveira, B.J. Feigl, L.G. Pimentel, I.P. Lisboa, M.R. Gmach, L.L. Varanda, M.C. Morais, L.S. Satiro, G.V. Popin, S.R. de Paiva, A.K.B. dos Santos, A.L.S. de Vasconcelos, P.L.A. de Melo, C.E.P. Cerri, C.C. Cerri, Crop residue harvest for bioenergy production and its implications on soil functioning and plant growth: A review, Scientia Agricola 75(3) (2018) 255-272.

10. M.M. Corradi, A.R. Panosso, M.V. Martins, N. La Scala, Crop residues on short-term $\mathrm{CO}_{2}$ emissions in sugarcane production areas, Engenharia Agricola 33(4) (2013) 699-708.

11. M.S. Neto, M.V. Galdos, B.J. Feigl, C.E.P. Cerri, C.C. Cerri, Direct $\mathrm{N}_{2} \mathrm{O}$ emission factors for synthetic Nfertilizer and organic residues applied on sugarcane for bioethanol production in Central-Southern Brazil, Global Change Biology Bioenergy 8(2) (2016) 269-280.

12. E.B. De Figueiredo, N. La Scala, Greenhouse gas balance due to the conversion of sugarcane areas from burned to green harvest in Brazil, Agriculture Ecosystems \& Environment 141(1-2) (2011) 77-85. 
13. IPCC, The Physical Science Basis. Working Group I Contribution to the Fifth Assessment Report of the Intergovernmental Panel on Climate Change, in: T.F. Stocker, D. Qin, G.-K. Plattner, M. Tignor, S.K. Allen, J. Boschung, A. Nauels, Y. Xia, V. Bex and P.M. Midgley (Ed.) http://www.ipcc.ch/report/ar5/wg1/ , 2013.

14. M.B.P.d.C. Glauco de Souza Rolim, Daniel Grosseli Lania, Classificação climática de Köppen e de Thornthwaite e sua aplicabilidade na determinação de zonas agroclimáticas para o estado de são Paulo, Bragantia 66 66(4) (2007) 711-720.

15. B.V. Raij, Quaggio, J.A., Cantarella, H., Ferreira, M.E., Lopes, A.S., Bataglia, O.C., Análise química do solo para fins de fertilidade, in: F. cargill (Ed.) Fundação cargill, 1987, p. 170.

16. EMBRAPA, Centro Nacional de Pesquisa de Solos. Manual de métodos de análise de solo, Ministério da Agricultura e do Abastecimento/EMBRAPA-CNPS, Brasília, Brazil, 1997.

17. IPCC, Chapter 11, N2O emissions from managed soils, and $\mathrm{CO} 2$ emissions from lime and urea application. , in: H.S. Eggleston, L. Buendia, K. Miwa, T. Ngara, K. Tanabe (Eds.), Guidelines for National Green House Gas Inventories, Prepared by the National Greenhouse Gas Inventories Programme., IGES, Japan, 2006.

18. M.R. Cherubin, I.P. Lisboa, A.G.B. Silva, L.L. Varanda, R.O. Bordonal, J.L.N. Carvalho, R. Otto, P.S. Pavinato, A. Soltangheisi, C.E.P. Cerri, Sugarcane Straw Removal: Implications to Soil Fertility and Fertilizer Demand in Brazil, Bioenergy Research 12(4) (2019) 888-900.

19. H.C.J. Franco, M.T.B. Pimenta, J.L.N. Carvalho, P.S.G. Magalhaes, C.E.V. Rossell, O.A. Braunbeck, A.C. Vitti, O.T. Kolln, J.R. Neto, Assessment of sugarcane trash for agronomic and energy purposes in Brazil, Scientia Agricola 70(5) (2013) 305-312.

20. L.C. Gonzaga, J.L.N. Carvalho, B.G. de Oliveira, J.R. Soares, H. Cantarella, Crop residue removal and nitrification inhibitor application as strategies to mitigate $\mathrm{N} 2 \mathrm{O}$ emissions in sugarcane fields, Biomass \& Bioenergy 119 (2018) 206-216.

21. A.L.S. Vasconcelos, M.R. Cherubin, B.J. Feigl, C.E.P. Cerri, M.R. Gmach, M. Siqueira-Neto, Greenhouse gas emission responses to sugarcane straw removal, Biomass and Bioenergy 113 (2018) 15-21.

22. IPCC, Chapter 2 Generic methodologies, in: H.S. Eggleston, L. Buendia, K. Miwa, T. Ngara, K. Tanabe (Eds.), Guidelines for National Green House Gas Inventories, Prepared by the National Greenhouse Gas Inventories Programme., IGES, Japan, 2006.

23. CETESB, Emissões veiculares no estado de São Paulo, in: G.d.E.d.S. Paulo (Ed.) https://cetesb.sp.gov.br/veicular/wp-content/uploads/sites/6/2013/12/Relat\%C3\%B3rioemiss\%C3\%B5es-veiculares-2014_VERS\%C3\%830-DIGITAL_01.09.pdf, 2014, p. 145.

24. IPCC, Chapter 03, Mobile combustion, in: H.S. Eggleston, L. Buendia, K. Miwa, T. Ngara, K. Tanabe (Eds.), Guidelines for National Green House Gas Inventories, Prepared by the National Greenhouse Gas Inventories Programme., IGES, Japan, 2006.

25. I.C. Macedo, J.E.A. Seabra, J.E.A.R. Silva, Green house gases emissions in the production and use of ethanol from sugarcane in Brazil: The 2005/2006 averages and a prediction for 2020, Biomass and Bioenergy 32(7) (2008) 582-595. 
26. G.A. Dantas, L.F.L. Legey, A. Mazzone, Energy from sugarcane bagasse in Brazil: An assessment of the productivity and cost of different technological routes, Renewable \& Sustainable Energy Reviews 21 (2013) 356-364.

27. D.J. Carvalho, J.P.S. Veiga, W.A. Bizzo, Analysis of energy consumption in three systems for collecting sugarcane straw for use in power generation, Energy 119 (2017) 178-187.

28. A.Y. Milanez, et al, De promessa a realidade: como o etanol celulósico pode revolucionar a indústria da cana-de-açúcar: uma avaliação do potencial competitivo e sugestões de política pública, BNDES, 2015, pp. 237-294.

29. R. Luiz Pinguelli, R. Suzana Kahn, Avoiding Emissions of Carbon Dioxide through the Use of Fuels Derived from Sugar Cane, Ambio 27(6) (1998) 465-470.

30. MCTI, Emissões corporativas, Ministério da Ciência, Tecnologia e Inovação, Brazil 2019., http://www.mctic.gov.br/mctic/opencms/ciencia/SEPED/clima/textogeral/emissao_corporativos.html 2019.

31. T. Vor, J. Dyckmans, N. Loftfield, F. Beese, $\mathrm{H}$. Flessa, Aeration effects on $\mathrm{CO}_{2}, \mathrm{~N}_{2} \mathrm{O}$, and $\mathrm{CH}_{4}$ emission and leachate composition of a forest soil, Journal of Plant Nutrition and Soil Science 166(1) (2003) 39-45.

32. A.J. Liska, H. Yang, M. Milner, S. Goddard, H. Blanco-Canqui, M.P. Pelton, X.X. Fang, H. Zhu, A.E. Suyker, Biofuels from crop residue can reduce soil carbon and increase $\mathrm{CO}_{2}$ emissions, Nature Climate Change 4(5) (2014) 398-401.

33. D.M.S. Oliveira, S. Williams, C.E.P. Cerri, K. Paustian, Predicting soil C changes over sugarcane expansion in Brazil using the DayCent model, GCB Bioenergy 9(9) (2017) 1436-1446.

34. J.B. do Carmo, S. Filoso, L.C. Zotelli, E.R.D. Neto, L.M. Pitombo, P.J. Duarte-Neto, V.P. Vargas, C.A. Andrade, G.J.C. Gava, R. Rossetto, H. Cantarella, A.E. Neto, L.A. Martinelli, Infield greenhouse gas emissions from sugarcane soils in Brazil: effects from synthetic and organic fertilizer application and crop trash accumulation, Global Change Biology Bioenergy 5(3) (2013) 267-280.

35. L.M. Pitombo, J.B. do Carmo, M. de Hollander, R. Rossetto, M.V. López, H. Cantarella, E.E. Kuramae, Exploring soil microbial 16S rRNA sequence data to increase carbon yield and nitrogen efficiency of a bioenergy crop, GCB Bioenergy 8(5) (2016) 867-879.

36. P.R. Adler, S.J.D. Grosso, W.J. Parton, Life-cycle assessment of net greenhouse-gas flux for bioenergy cropping systems, Ecological Applications 17(3) (2007) 675-691.

37. P.J. Crutzen, A.R. Mosier, K.A. Smith, W. Winiwarter, $\mathrm{N}_{2} \mathrm{O}$ release from agro-biofuel production negates global warming reduction by replacing fossil fuels, Atmospheric Chemistry and Physics 8(2) (2008) 389-395.

38. M.K. Firestone, E.A. Davidson, Microbiological basis of $\mathrm{NO}$ and $\mathrm{N}_{2} \mathrm{O}$ production and consumption in soils, in: M.O. Andreae, D.S. Schimel (Eds.), Exchange of Trace Gases between Terrestrial Ecosystems and the Atmosphere, John Wiley and Sons, Chichester, 1989.

39. J.E.A. Seabra, L. Tao, H.L. Chum, I.C. Macedo, A techno-economic evaluation of the effects of centralized cellulosic ethanol and co-products refinery options with sugarcane mill clustering, Biomass 
and Bioenergy 34(8) (2010) 1065-1078.

40. O. Cavalett, M.F. Chagas, T.L. Junqueira, M.D.B. Watanabe, A. Bonomi, Environmental impacts of technology learning curve for cellulosic ethanol in Brazil, Industrial Crops and Products 106 (2017) 3139.

\section{Figures}

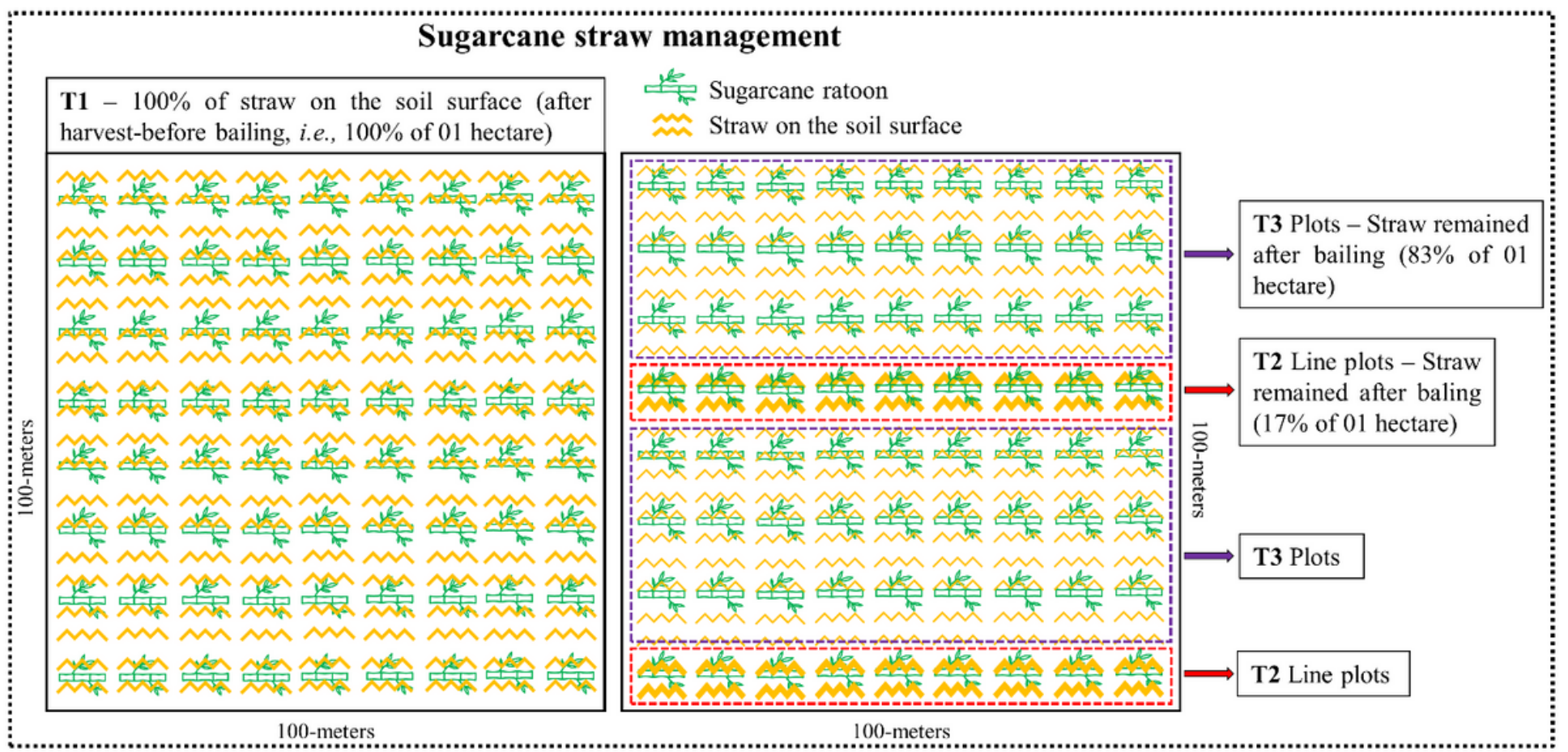

\section{Figure 1}

Schematic figure showing $\mathrm{T} 1$ area, with $100 \%$ of straw maintained on the soil surface; $\mathrm{T} 2$, line plots where straw was heaped for subsequent baling (i.e., 17\% of 01 hectare) and T3 area where straw was recovered from six lines per each passing of a tractor (i.e., $83 \%$ of 01 hectare). 

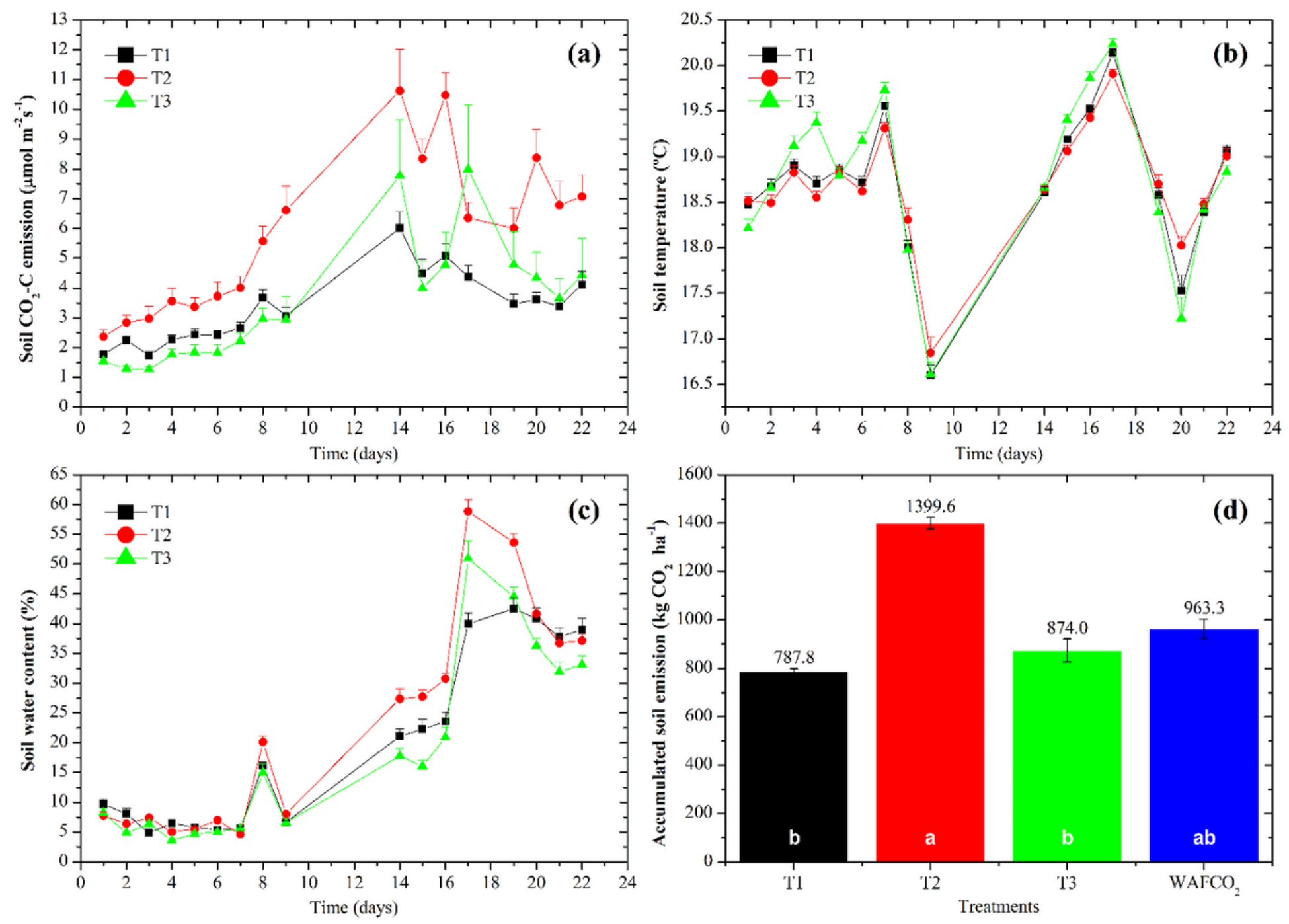

Figure 2

$(\mathrm{a}, \mathrm{b}, \mathrm{c}$ and d). a) Soil CO2-C emissions ( $\mu \mathrm{mol} \mathrm{m}-2 \mathrm{~h}-1)$; b) soil temperature $\left({ }^{\circ} \mathrm{C}\right)$; c) soil water content (\%) plus standard errors (vertical bars) and d) Accumulated soil CO2-C emission (plus standard error, $\mathrm{kg} \mathrm{CO} 2-\mathrm{C}$ ha -1) for T1: Control area, with straw maintained on the soil surface; T2: Line plots where straw was recovered and accumulated in one line and later collected for baling (17\% of harvest area); T3: Areas where the normal mechanized straw harvesting operations were performed ( $83 \%$ of harvested area); WAFCO2: Weighted average of soil FCO2 (weighted average of emission in T2 and the T3). Means followed by the same letters comparing straw management types did not differ by the Tukey test $(P<0.05)$. 


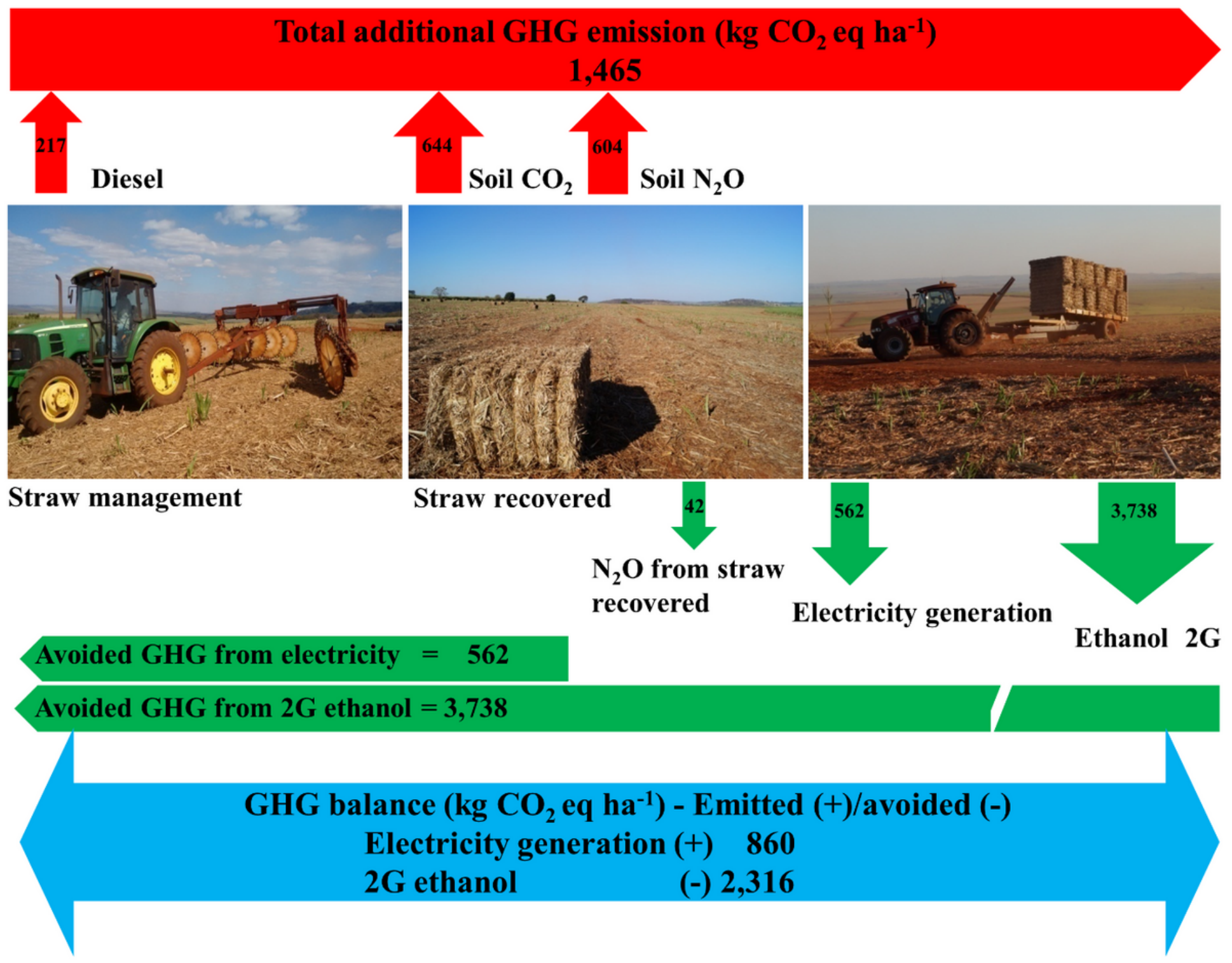

Figure 3

Additional GHG emissions (red bars), offset potential (green bars) and GHG balance (Blue bar), from sugarcane straw management and recovery operations that would be used for bioelectricity or ethanol $2 \mathrm{G}$ production (All values in $\mathrm{kg}$ CO2eq ha-1 for a straw recovering rate of 6.89 ton DM ha-1). 